\title{
Natural isotopic composition of nitrogen in suspended particulate matter in the Bay of Bengal
}

\author{
S. Kumar ${ }^{1}$, R. Ramesh ${ }^{1}$, N. B. Bhosle ${ }^{2}$, S. Sardesai ${ }^{2}$, and M. S. Sheshshayee ${ }^{3}$ \\ ${ }^{1}$ Planetary and Geosciences Division, Physical Research Laboratory, Navrangpura, Ahmedabad- 380 009, India \\ ${ }^{2}$ Chemical Oceanography Divivsion, National Institute of Oceanography, Dona Paula, Goa-403 004, India \\ ${ }^{3}$ Department of Crop Physiology, University of Agricultural Sciences, GKVK Campus, Bangalore-560 065, India
}

Received: 26 April 2004 - Published in Biogeosciences Discussions: 4 June 2004

Revised: 11 September 2004 - Accepted: 6 October 2004 - Published: 14 October 2004

\begin{abstract}
We present the first measurements of nitrogen isotopic composition $\left(\delta^{15} \mathrm{~N}\right)$ in suspended particulate matter (SPM) of the surface Bay of Bengal (BOB) at 24 different locations during pre- (April-May 2003) and post- (SeptemberOctober 2002) monsoon seasons. The $\delta^{15} \mathrm{~N}$ values of particulate organic nitrogen (PON) in surface suspended matter of coastal and northern open BOB show mixing between continental inputs and marine sources. Dilution by continental material brought in by rivers leads to consistently lower $\delta^{15} \mathrm{~N}$, evident from the relationship between surface salinity and $\delta^{15} \mathrm{~N} . \delta^{15} \mathrm{~N}$ values of surface PON of open ocean locations during both seasons, and also at coastal locations during premonsoon suggest nitrate from deeper waters to be a predominant source of nutrients for phytoplankton. The depth profiles of $\delta^{15} \mathrm{~N}$ of PON during the premonsoon season at nine different locations indicate an increase in $\delta^{15} \mathrm{~N}$ by a maximum of $2.8 \%$ o between euphotic depth and $300 \mathrm{~m}$. These changes are less than those observed in the far eastern Indian Ocean, indicating higher sinking rates of particles ballasted by aggregates of organic and mineral matter in BOB.
\end{abstract}

\section{Introduction}

Particulate organic matter (POM) is known to play an important role in marine nitrogen and carbon cycles (Saino and Hattori, 1980). The study of the nitrogen isotope ratio ${ }^{15} \mathrm{~N} /{ }^{14} \mathrm{~N}\left(\delta^{15} \mathrm{~N}\right.$, expressed as deviation in per mil $(\%)$ from that of atmospheric $\mathrm{N}_{2}$ ) of POM provides an insight into the availability and utilization of nutrients and the transformation processes it undergoes during its transportation to greater depths. Several such studies have been done in different parts of the world ocean (Wada and Hattori, 1976; Saino and Hattori, 1980; Altabet, 1996). Similar studies on ocean sediments have been used for the reconstruction of past

Correspondence to: S. Kumar

(sanjeev@prl.ernet.in) changes in surface ocean nutrient utilization (e.g. Altabet and Francois, 1994; Farrell et al., 1995).

The $\delta^{15} \mathrm{~N}$ of the marine particulate organic nitrogen (PON) has a strong dependence on the $\delta^{15} \mathrm{~N}$ of source nitrogen (atmospheric $\mathrm{N}_{2}, \mathrm{NO}_{3}^{-}$and $\mathrm{NH}_{4}^{+}$). $\delta^{15} \mathrm{~N}$ of marine $\mathrm{PON}$ shows a wide variation (Saino and Hattori, 1980; Altabet, 1988; Rau et al., 1998), due to the changes in $\delta^{15} \mathrm{~N}$ of source, caused by fractionation of isotopes during various biogeochemical/biological processes involved during its formation. These processes are $\mathrm{N}_{2}$ fixation, denitrification, nitrification, and nitrate assimilation. Denitrification leads to ${ }^{15} \mathrm{~N}$ enrichment of the remaining nitrate while nitrification causes enrichment of ${ }^{15} \mathrm{~N}$ in the ammonium pool (Mariotti et al., 1984). Enrichment of up to $20 \%$ in the remaining pool has been found due to denitrification (Miyake and Wada, 1971; Cline and Kaplan, 1975), nitrification (Miyake and Wada, 1971) and nitrate assimilation (Wada et al., 1971). During the uptake of dissolved nitrogen in eutrophic waters, phytoplankton prefer ${ }^{14} \mathrm{~N}$ to ${ }^{15} \mathrm{~N}$ (Wada and Hattorri, 1978). Cynobacterial fixation of atmospheric nitrogen is known to lower the $\delta^{15} \mathrm{~N}$ of PON (0.6\% ; Emerson et al., 1991) because of the depleted source (atmospheric $\mathrm{N}_{2}, 0 \%$ ). Therefore, the areas with lower $\delta^{15} \mathrm{~N}$ may involve $\mathrm{N}_{2}$ fixation. Furthermore, the $\delta^{15} \mathrm{~N}$ of PON in marine organic matter also depends on phytoplankton species (composition), physiology and the rate and phase of growth of phytoplankton (Montoya and McCarthy, 1995).

This study reports the first detailed observations of $\delta^{15} \mathrm{~N}$ of suspended PON in the Bay of Bengal (BOB), the eastern counterpart of Arabian Sea in the northern Indian Ocean, where data on $\delta^{15} \mathrm{~N}$ of suspended matter is scarce (Saino and Hattori, 1980). We examined the observed variation in ${ }^{15} \mathrm{~N}$ and PON content in two different seasons i.e. post- (September-October 2002) and premonsoon (AprilMay 2003). The vertical profiles of $\delta^{15} \mathrm{~N}$ in suspended matter at different locations, and the depth related changes during the premonsoon season are discussed. 


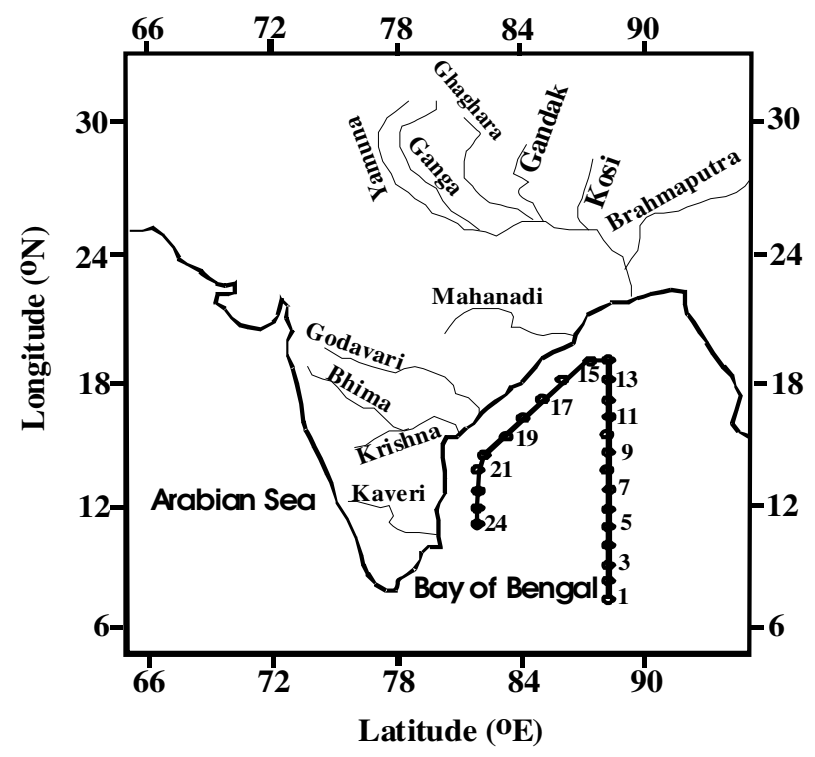

Fig. 1. Cruise track along which the study was performed during both seasons. Major rivers draining into the Bay of Bengal are also shown. Dots are the stations.

\section{Material and methods}

Sampling was performed along the cruise track shown in Fig. 1, onboard ORV Sagar Kanya, as a part of Bay of Bengal process study (BOBPS). The duration of sampling was from 17 September to 11 October 2002 (postmonsoon; SK-182) and from 16 April to 6 May 2003 (premonsoon; SK-191). Surface seawater samples were collected using a clean plastic bucket and thirty litre Go Flo bottles attached to a CTD rosette were used to collect seawater samples from various depths (up to $500 \mathrm{~m}$ ). Immediately after collection, four to six litres of sea water were filtered through a precombusted $\left(400^{\circ} \mathrm{C}\right.$ for $\left.4 \mathrm{~h}\right)$ Whatman $\mathrm{GF} / \mathrm{F}$ glass fibre filter $(47 \mathrm{~mm}$ diameter, $0.7 \mu \mathrm{m}$ pore size). After the filtration the samples were dried at $60^{\circ} \mathrm{C}$ and stored at room temperature for isotopic analysis in the shore laboratory.

Measurements of nitrogen isotope ratio and PON were carried out using a Carlo Erba elemental analyser interfaced via ConfloIII to a Finnigan Delta Plus mass spectrometer. Due to the small amount of nitrogen gas recovered from the samples (typically $<1 \mu \mathrm{MN}$ ), for precise analysis, the method of Owens and Rees (1989) with a modification in oxygen injection time was used. Integration of areas under the masspeaks 28,29 and 30 after calibration with standard material (IAEA-NO-3, $\mathrm{KNO}_{3}$ ) of known stoichiometry provided the measurement of PON. The advantage of this technique lies in the simultaneous measurement of isotope ratio and PON in the same sample. PON was measured to a precision of less than $10 \%$, while that for $\delta^{15} \mathrm{~N}$ was $0.3 \%$. $\delta^{15} \mathrm{~N}$ measurement of the standard (IAEA-NO-3, $\mathrm{KNO}_{3}, \delta^{15} \mathrm{~N}=4.7 \%$ ) yielded a value of $4.9 \pm 0.3 \%$ o $(n=19)$. Ambient nitrate concentration during present study was measured by the column reduction technique (Strickland and Parson, 1972).

\section{Study area: hydrography and nutrients}

The BOB is a semi-enclosed tropical basin in the northern Indian Ocean. It experiences seasonal changes in circulation and weather due to the seasonally reversing monsoons. BOB receives excess precipitation $(\sim 2 \mathrm{~m})$ and large quantities of freshwater influx $\left(1.6 \times 10^{12} \mathrm{~m}^{3} \mathrm{yr}^{-1}\right.$ compared to $0.3 \times 10^{12} \mathrm{~m}^{3} \mathrm{yr}^{-1}$ of Arabian Sea; Subramanian, 1993) from the major rivers draining the Indian subcontinent. This freshwater input results in considerable salinity variations during and after the monsoon over the whole basin, thereby inducing stratification of the upper $100 \mathrm{~m}$ of the water column (Prasanna Kumar et al., 2002). The surface salinity of the open ocean stations during postmonsoon decreased from south to north ( $34 \mathrm{psu}$ at $7^{\circ} \mathrm{N}$ to $32 \mathrm{psu}$ at $16^{\circ} \mathrm{N}$ ) and dropped by 3 psu at $17^{\circ} \mathrm{N}$. The coastal stations showed a similar pattern of salinity but the drop was more pronounced from $16^{\circ} \mathrm{N}$ to $17^{\circ} \mathrm{N}$ ( 34 psu to $21 \mathrm{psu}$ ). During premonsoon the overall variation in salinity was between 32 to 34 psu.

Sea surface temperature (SST) during postmonsoon along open BOB varied marginally from 28.2 to $29^{\circ} \mathrm{C}$ from south to north, while along coastal transect it did not show any trend and the average was around $30^{\circ} \mathrm{C}$. During premonsoon SST varied from 29 to $31.4^{\circ} \mathrm{C}$ in the open ocean and showed a decrease of $\sim 2^{\circ} \mathrm{C}$ from $14^{\circ} \mathrm{N}$ to $15^{\circ} \mathrm{N}$. For the coastal locations, it varied from $29.1{ }^{\circ} \mathrm{C}$ to $30.4^{\circ} \mathrm{C}$.

The riverine inputs are a major potential source of nutrients such as nitrate, phosphate and silica to the Bay. Also, one of the major suppliers of the nutrients to the surface Bay is mixing due to cyclones, frequent in the $\mathrm{BOB}$ during postmonsoon season. The formation of localized intense blooms and also the intensification of bloom generated by anticyclonic gyre is known due to injection of nutrients by cyclonic activity (Vinaychandran and Mathew, 2003). During the premonsoon period there is a poleward East India Coastal Current (EICC) active at north of $10^{\circ} \mathrm{N}$ which brings cooler, more saline water with nutrients to the surface (Shetye et al., 1993). Upwelling has also been observed along the western boundary of the basin in a $40 \mathrm{~km}$ wide band due to local longshore wind stress (Shetye et al., 1991). The measured nitrate concentrations in the surface Bay are presented in Fig. 2. In general, the surface nitrate during postmonsoon was very low (mostly below detection limit, $<0.1 \mu \mathrm{M}$ ) and for premonsoon it was mostly around $0.2 \mu \mathrm{M}$. However, it increased sharply between 40 and $60 \mathrm{~m}$ (maximum $\sim 15 \mu \mathrm{M}$ and average $\sim 7 \mu \mathrm{M}$ during premonsoon). The Bay of Bengal water is well oxygenated relative to the Arabian Sea. During the premonsoon oxygen concentrations ranging from $150-175 \mu \mathrm{M}$ in surface mixed layer were observed in open and coastal regions. During the postmonsoon oxygen minimum zone (OMZ) with oxygen concentration $<10 \mu \mathrm{M}$ was observed 


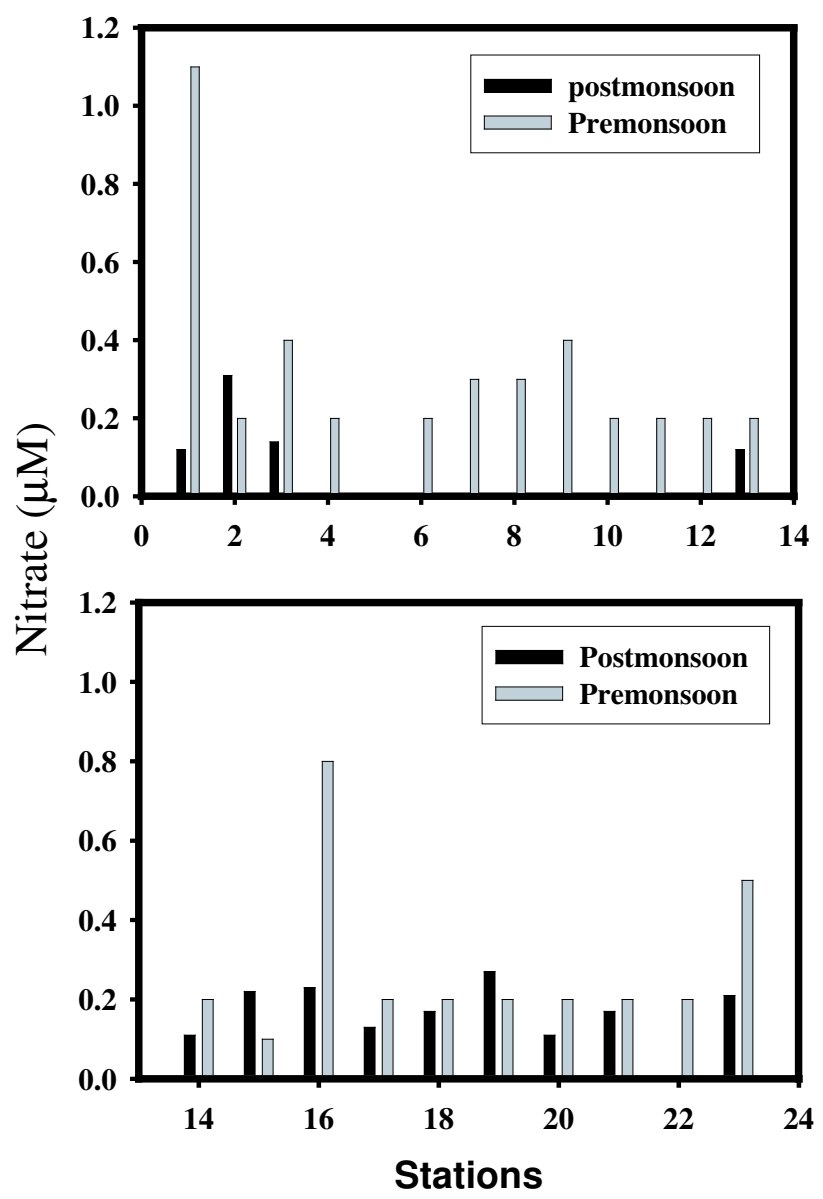

Fig. 2. Surface nitrate concentrations at different stations during post- (dark bars) and pre- (light bars) monsoon. The absence of bars indicates values below the detection limit $(<0.1 \mu \mathrm{M})$.

between depths of around 60 to $400 \mathrm{~m}$ from 14 to $20^{\circ} \mathrm{N}$ in the open Bay. During premonsoon the OMZ was confined to a smaller area i.e. from 19 to $20^{\circ} \mathrm{N}$ between 80 to $120 \mathrm{~m}$ which extended to $14^{\circ} \mathrm{N}$ between 100 to $300 \mathrm{~m}$. OMZ was much thicker and was seen from 11 to $20^{\circ} \mathrm{N}$ between approximately 120 to $500 \mathrm{~m}$ in the coastal region during postmonsoon but showed shoaling up to $60 \mathrm{~m}$ around $17^{\circ} \mathrm{N}$ during premonsoon. Pockets of very low concentration of oxygen $(<5 \mu \mathrm{M})$ were also observed in the coastal region. Despite such low oxygen concentrations significant secondary nitrite levels or decrease in nitrate levels in the region of $\mathrm{OMZ}$ to suggest denitrification during the study period were not encountered.

\section{Results}

Stations studied are divided into two transects: one along the $88^{\circ}$ E longitude (Stn.1-Stn.13), defined here as open ocean stations (transect) and the other parallel to the Indian coast (Stn.14 to Stn.24) as the coastal stations (transect).

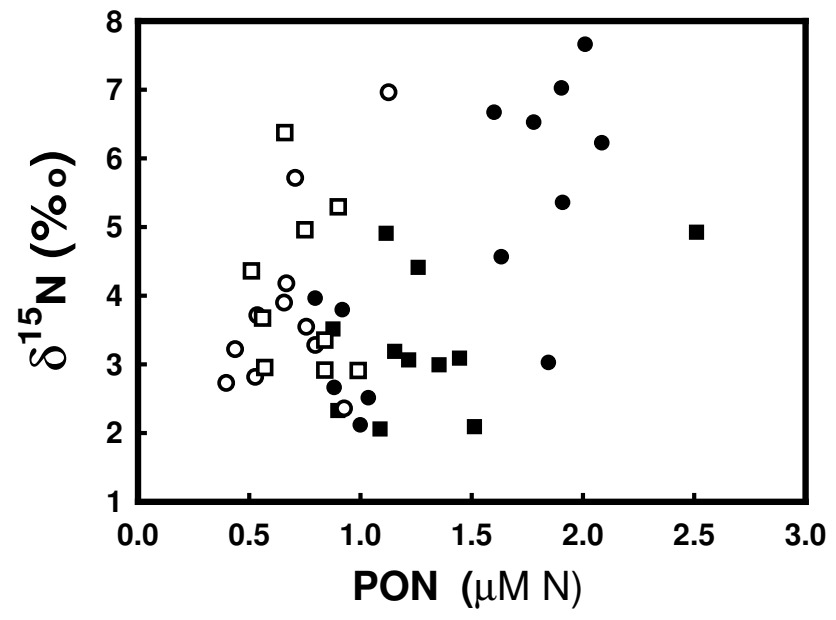

Fig. 3. The relationship between $\delta^{15} \mathrm{~N}$ and PON during post- (filled circles and squares represent open ocean and coastal stations) and premonsoon (open circle and squares represent open ocean and coastal stations).

\subsection{Surface suspended matter}

Overall, it has been observed that the average surface PON concentration during postmonsoon season $(1.4 \mu \mathrm{MN})$ is nearly twice that of premonsoon $(0.7 \mu \mathrm{MN})$. During the postmonsoon the difference in average coastal $(1.3 \mu \mathrm{MN})$ and open ocean $(1.4 \mu \mathrm{MN})$ surface PON is insignificant. The same is true for the premonsoon season, where it averages $0.7 \mu \mathrm{MN}$ for coastal and $0.6 \mu \mathrm{M} \mathrm{N}$ for open ocean locations. During the whole period of study, the maximum surface PON of $2.5 \mu \mathrm{M} \mathrm{N}$ has been observed at Stn.15, which is the nearest to the coast with the shallowest water column depth of $620 \mathrm{~m}$. The $\delta^{15} \mathrm{~N}$ values of surface PON for both pre- and postmonsoon season range from 2 to $7.6 \%$ and fall in the general range of known oceanic PON $\delta^{15} \mathrm{~N}$. The overall $\delta^{15} \mathrm{~N}$ of surface PON averages around $4.1 \%$ for postmonsoon and $3.8 \%$ for premonsoon season, which agree within analytical error. There is a significant difference of $1.5 \%$ between average $\delta^{15} \mathrm{~N}$ of open ocean (4.8\%o) and coastal (3.3\%o) stations during postmonsoon. However, no such difference has been observed for the samples collected during premonsoon, where both average around 4\%o. There is no significant latitudinal variation in $\delta^{15} \mathrm{~N}$ during either season. There exists a positive linear correlation between PON and $\delta^{15} \mathrm{~N}$ (Fig. 3). This relationship is more significant during postmonsoon $\left(\mathrm{R}^{2}=0.42, \mathrm{n}=24, \mathrm{p}=0.005 ; \delta^{15} \mathrm{~N}=2.35 * \mathrm{PON}+0.78\right)$ than premonsoon $\left(\mathrm{R}^{2}=0.21, \mathrm{n}=22, \mathrm{p}=0.025 ; \delta^{15} \mathrm{~N}=4.05 * \mathrm{PON}+0.74\right)$. During postmonsoon the coastal stations show less variability and data points lie in the lower regime i.e. low PON- low $\delta^{15} \mathrm{~N}$ zone. On the other hand, the open ocean stations show two clusters of data points, one with low PON-low $\delta^{15} \mathrm{~N}$ which averages around 3.0\%o and other with high PON-high $\delta^{15} \mathrm{~N}$ with an average of 5.8\%o. During premonsoon no clear 
cut distinction exists between $\delta^{15} \mathrm{~N}$ of PON in coastal and open ocean transects.

\subsection{Depth profiles of suspended matter}

Figure 4 presents the vertical profiles of $\delta^{15} \mathrm{~N}$ and PON for premonsoon season at different locations upto $300 \mathrm{~m}$ or more except Stn.3, where it is only up to $100 \mathrm{~m}$. Average $\delta^{15} \mathrm{~N}$ of PON in the top $\sim 60 \mathrm{~m}$ varies between 1.9 to $4.9 \%$ ofor different stations with an average of $4.2 \%$. Below this, $\delta^{15} \mathrm{~N}$ increases with depth and reaches an average value of 5.9\%o at $300 \mathrm{~m}$. For the open ocean stations the average euphotic zone $\delta^{15} \mathrm{~N}$ shows a decreasing trend from south to north with a maximum of $4.5 \%$ or for southernmost station (Stn.23) and minimum of $2.9 \%$ for northern station (Stn.12). $\delta^{15} \mathrm{~N}$ also shows subsurface minima between 10 to $60 \mathrm{~m}$ varying with location. PON, in general, decreases with depth showing subsurface maxima within the euphotic zone. Euphotic zone average of PON is $0.7 \mu \mathrm{MN}$ which decreases to $0.3 \mu \mathrm{MN}$ at $300 \mathrm{~m}$.

\section{Discussion}

In oceanic environments, PON is mainly derived form phytoplankton, micro-zooplankton, bacteria and detritus. The nitrogen isotopic signature of $\mathrm{PON}$ in suspended matter depends on the isotopic fractionation associated with its formation, and in turn upon the isotopic composition of inorganic form of dissolved nitrogenous sources (such as $\mathrm{NO}_{3}^{-}$, $3-7 \%$; $\mathrm{NH}_{4}^{+}, 6-8 \%$; and atmospheric $\mathrm{N}_{2}, 0 \%$; Miyake and Wada, 1967) available for the utilization by phytoplankton. The variation in $\delta^{15} \mathrm{~N}$ of PON reveals the utilization of different nitrogen sources by planktons as these sources have distinct isotopic compositions. Microscopic study suggested absence of Trichodesmium during the postmonsoon and diatoms were found to be the dominant species. However, there were sporadic occurrences of Trichodesmium during premonsoon but it did not dominate in terms of $\mathrm{N}$ contribution to the PON (N. Ramaiah, personal communication). Our $\delta^{15} \mathrm{~N}$ data also precludes the possibility of significant $\mathrm{N}_{2}$ fixation in BOB, as the cyanobacteria Trichodesmium; a well known $\mathrm{N}_{2}$ fixer generates PON with a $\delta^{15} \mathrm{~N}$ value $(0.6 \%$ ) nearer to the atmospheric $\mathrm{N}_{2}$ in equilibrium with seawater (Emerson et al., 1991). $\delta^{15} \mathrm{~N}$ values around -2 to $0 \%$ o has also been reported for cyanobacteria Trichodesmium (Minagawa and Wada, 1986). All our $\delta^{15} \mathrm{~N}$ data are above the required value for an area dominated by $\mathrm{N}_{2}$ fixers.

\subsection{Surface suspended matter}

For the purpose of discussion, stations in BOB may be classified into two based on the surface salinity of the stations. The first includes the stations with salinity less than $32 \mathrm{psu}$ (the six coastal stations and three open ocean stations during postmonsoon; Fig. 5) and second includes the stations with surface salinity more than 32 psu (all the rest). The former are influenced by the riverine discharge whereas the latter are not.

The salinity and $\delta^{15} \mathrm{~N}$ of suspended PON (Fig. 5) for the two seasons indicate that when salinity is low $(<32 \mathrm{psu})$, the $\delta^{15} \mathrm{~N}$ is consistently on the lower side (2-3\%o) (except at one location each in coastal and open ocean, which have $\delta^{15} \mathrm{~N}$ values of 4.9 and $4.6 \%$ respectively). The rivers draining the BOB bring a lot of terrestrial organic as well as detrital material (Unger et al., 2003). The consistent low $\delta^{15} \mathrm{~N}$ suggests that isotopic signature of $\mathrm{PON}$ at these locations have been influenced by terrestrial inputs. Terrestrial particulate matter, brought by major rivers, might have diluted the overall $\delta^{15} \mathrm{~N}$ signal of PON, although there exists no literature regarding the $\delta^{15} \mathrm{~N}$ of such particulate matter draining into BOB. But, the naturally occurring land derived materials are known to have low $\delta^{15} \mathrm{~N}$ (mean of $2.5 \%$ for terrestrial organic matter, Sweeney et al., 1978; and 1.5\%o for terrestrial detrital component, Mariotti et al., 1984). Also, the C:N values in suspended matter during postmonsoon at locations under terrestrial influence have been found to be relatively higher $(9.5$, 9.3 and 8.2 at stations 12,16 and 18 respectively) compared to stations without influence $(5,3.4,4.6,6.2$ and 6.4 for stations $3,6,9,20$ and 23 respectively), indicating the contribution of continental inputs at these stations.

The stations which are not influenced by riverine discharge show a wide isotopic variability $(2-7.6 \%$ ). However, high average $\delta^{15} \mathrm{~N}$ of surface suspended matter $(5.3 \%$ o for open ocean stations during postmonsoon and $4 \%$ for both open and coastal stations during premonsoon) have been observed for these stations. Since these locations are unaffected by the terrestrial influence the variability observed may be attributed to the two possible reasons: first, uptake of regenerated ammonium (Wada and Hattori, 1976); and second, supply of nitrate from deeper waters due to the presence of shallow nitracline, which is between 50-100 m (Prasanna Kumar et al., 2002).

In the former case, regenerated ammonium produced by excretion of zooplankton and heterotrophs in the surface layer has been considered as a source. In most oceanic regions, ammonium is the preferred substrate and normally does not accumulate in the surface layer (Mino et al., 2002). Soon after regeneration of ammonium, it is rapidly taken up by the algae; there is little time for isotopic fractionation and the $\delta^{15} \mathrm{~N}$ of ammonium is imprinted in PON without much modification. Unfortunately, $\delta^{15} \mathrm{~N}$ of ammonium in the BOB has not been measured to directly assess the role of ammonium on $\delta^{15} \mathrm{~N}$ of PON. Values in the range of 6-8\%o have been reported for ammonium in other oceans (Miyake and Wada, 1967). However, indirect estimation of degree of contribution of ammonium in $\delta^{15} \mathrm{~N}$ of PON may be obtained from new production (Dugdale and Goering, 1967) measurements in the region (Kumar et al., 2004). If the new production is less, there could be a prominent effect of the regenerated ammonium on the $\delta^{15} \mathrm{~N}$ of PON. But in BOB, in 


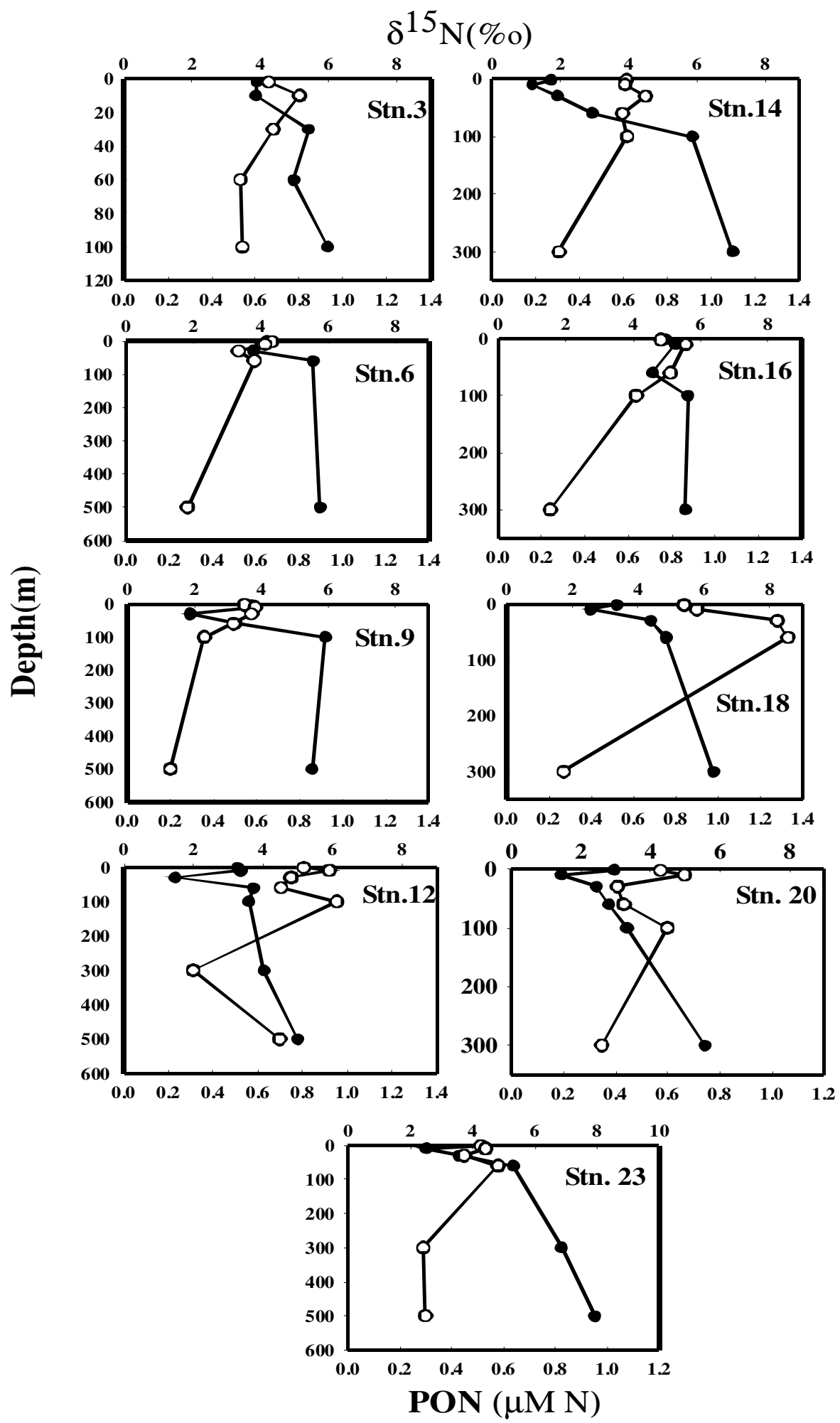

Fig. 4. The depth profiles of $\delta^{15} \mathrm{~N}$ and PON during premonsoon at different stations. The filled and unfilled circles indicate $\delta^{15} \mathrm{~N}$ and PON respectively. 


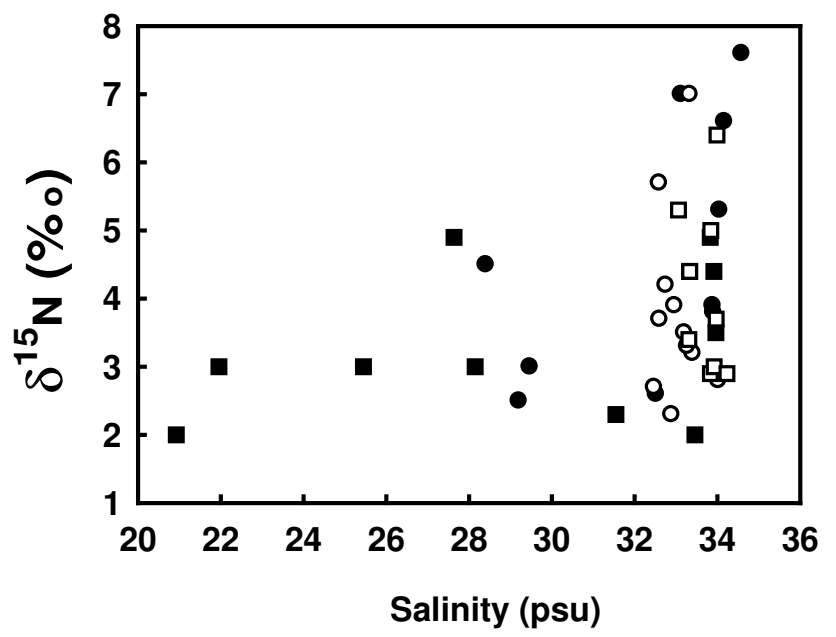

Fig. 5. The relationship between salinity and $\delta^{15} \mathrm{~N}$ for pre- and postmonsoon seasons. Legend same as Fig. 3.

general, high new production has been observed by us during both post- (average $\sim 4 \mathrm{mmol} \mathrm{N} \mathrm{m}^{-2} \mathrm{~d}^{-1}$ ) and pre- (average $\sim 5.4 \mathrm{mmol} \mathrm{N} \mathrm{m}^{-2} \mathrm{~d}^{-1}$ ) monsoon. Therefore, regenerated ammonium is likely to have played a limited role in observed $\delta^{15} \mathrm{~N}$ of PON. However, significant ammonium contributions cannot be ruled out for three locations in the open ocean during postmonsoon and at one location during premonsoon, where values higher than $6 \%$ o have been observed.

The nitrate from deeper water is a known source of nutrients in the Indian Ocean for phytoplankton (Vinaychandran and Mathew, 2003); however, its possible imprint on $\delta^{15} \mathrm{~N}$ of PON and related fractionation mechanism could only be estimated if the nitrate $\delta^{15} \mathrm{~N}$ is known. But, as in the case of ammonium, nitrate $\delta^{15} \mathrm{~N}$ has also not been measured in the Bay. $\delta^{15} \mathrm{~N}$ values of 3-7\% o have been reported for nitrate in deeper waters lacking significant column denitrification as in BOB (Miyake and Wada, 1967; Cline and Kaplan, 1975). The average value reported here for $\delta^{15} \mathrm{~N}$ of PON in open ocean during both post- and premonsoon seasons (5.3 and 4\%) are found to be of similar magnitude. However, the observed variability can be explained in two different ways: first, the rapid uptake of the nitrate without fractionation and second, the fractionation of nitrate during uptake by the phytoplankton. In the first scenario, the consumption of nitrate has to be fast enough for little or no isotopic fractionation and the original $\delta^{15} \mathrm{~N}$ of nitrate would be reflected in the $\delta^{15} \mathrm{~N}$ of PON (Altabet and McCarthy, 1985; Wada and Hattori, 1991). In this case, complete consumption of nitrate from the surface would be expected. The open ocean stations during postmonsoon show the virtual absence of nitrate (below the level of detection; Fig. 2) from the surface, implying its complete consumption. However, there is variability $(2.1$ to $7.6 \%$ ) in the $\delta^{15} \mathrm{~N}$ of PON at these open ocean stations despite undetectable ambient nitrate. Out of the thirteen stations, ten have $\delta^{15} \mathrm{~N}$ ranging from 3 and $7.6 \%$, falling in the range of $\delta^{15} \mathrm{~N}$
Table 1. $\delta^{15} \mathrm{~N}$ of particulate organic nitrogen in surface suspended matter from different oceanic regions of the world.

\begin{tabular}{lll}
\hline Oceanic regions & $\delta^{15} \mathrm{~N}(\%)$ & References \\
\hline Southern Ocean & & \\
$\quad$ Subantarctic zone & $\sim 1$ & Lourey et al. (2003) \\
$\quad$ Polar Frontal zone & 0 to -4 & Lourey et al. (2003) \\
Atlantic Ocean & -0.8 to 5.4 & Mino et al. (2002) \\
Monterey Bay & 1.3 to 7.6 & Rau et al. (1998) \\
Sargasso Sea (annual Av) & 0.2 & Altabet (1988) \\
Northeastern Indian Ocean & 2.1 to 10.1 & Saino and Hattori (1980) \\
Bay of Bengal & 2 to 7.6 & Present Study \\
\hline
\end{tabular}

for oceanic nitrate as mentioned earlier. This variability in $\delta^{15} \mathrm{~N}$ of PON indicates the possibility of change in isotopic composition of source nitrate. $\delta^{15} \mathrm{~N}$ for 3 stations falls below $3 \%$ and cannot be explained by above mentioned complete consumption argument.

The $\delta^{15} \mathrm{~N}$ at premonsoon locations vary from 2.7 to $7 \%$ with relatively higher surface nitrate concentration $(0.2$ to $1.1 \mu \mathrm{M})$. This availability of nitrate pool in the surface water suggests that the phytoplankton have the luxury of discriminating in favour of ${ }^{14} \mathrm{~N}$ during uptake. The exact mechanism by which these nutrients reach the surface in the open Bay during premonsoon is a subject of speculation. However, nitrate for coastal locations during premonsoon might have been supplied by the EICC acting north of about $10^{\circ} \mathrm{N}$. The EICC is best developed during March-Apr and decays only by June (Shetye et al., 1993).

As mentioned earlier, $\delta^{15} \mathrm{~N}$ of suspended matter in BOB varies from 2 to $7.6 \%$ falling in the known oceanic range $(-5$ to $+15 \%$; Wada and Hattori, 1991). However, the latter is known to fall in different ranges depending on the nitrogen source and fractionation by the phytoplankton. Table 1 compares a few recent studies of $\delta^{15} \mathrm{~N}$ in suspended matter of the world ocean. Rau et al. (1998) observed values in the Monterey Bay varying beween 1.3 to $7.6 \%$, similar to our range. Mino et al. (2002) have studied near surface waters along $50^{\circ} \mathrm{N}$ to $50^{\circ} \mathrm{S}$ in the Atlantic Ocean and the values ranged from -0.8 to $5.4 \%$. The negative relationship between $\delta^{15} \mathrm{~N}$ of PON and nitrate concentration as observed by Rau et al. (1998) and Mino et al. (2002) was not observed by us. Relatively higher values (4-6\%o) observed by Mino et al. (2002) have been attributed to the rapid consumption of nitrate from deeper waters similar to a few open ocean stations during the postmonsoon of the present study.

Overall, the $\delta^{15} \mathrm{~N}$ values of PON in the surface waters observed in the Bay may be explained in terms of mixing between (i) the terrestrial particulate matter with low $\delta^{15} \mathrm{~N}$, which has mostly influenced the six coastal locations and three open ocean locations during postmonsoon, and (ii) marine phytoplankton, which has mainly inherited the $\delta^{15} \mathrm{~N}$ of 
nitrate from deeper waters. However, the phytoplankton have a wide spectrum of values because of two extremes: one due to uptake of nitrate without fractionation (highest $\delta^{15} \mathrm{~N}$ ) and other with high degree of fractionation (lowest $\delta^{15} \mathrm{~N}$ ).

\subsection{Depth profile of $\delta^{15} \mathrm{~N}$ suspended matter}

The depth related distribution of $\delta^{15} \mathrm{~N}$ in suspended matter is in agreement with the general pattern observed in the world ocean i.e. it increases with depth (Saino and Hattori, 1980). At most locations there is an increase in $\delta^{15} \mathrm{~N}$ below $60 \mathrm{~m}$. This increase is 0.21 to $2.8 \%$ o between 60 and $300 \mathrm{~m}$. High $\delta^{15} \mathrm{~N}$ below euphotic depth has been observed mainly due to two reasons: (1) degradation of suspended matter itself causing the preferential release of ${ }^{14} \mathrm{~N}$ leaving the remaining PON enriched in ${ }^{15} \mathrm{~N}$. (2) Production of PON due to fragmentation of sinking particles below the euphotic depth (Bacon et al., 1985). These sinking particles are enriched in $\delta^{15} \mathrm{~N}$ by $3-4 \%$ 。 relative to suspended particle in euphotic zone because these particles are formed as a by-product of zooplankton feeding, causing an increase in $\delta^{15} \mathrm{~N}$ with each trophic step (DeNiro and Epstein, 1981). There is no data regarding $\delta^{15} \mathrm{~N}$ of sinking particles for BOB at 300 or $500 \mathrm{~m}$ depths. However, the sediment traps placed at around $2000 \mathrm{~m}$ show $\delta^{15} \mathrm{~N}$ variation in the range of 2.2-6.2\%o (Schafer and Ittekkot, 1995). But $\delta^{15} \mathrm{~N}$ of deeper PON ( $2000 \mathrm{~m}$ ) is known to be less (Saino and Hattori, 1987) as it starts decreasing below $500 \mathrm{~m}$. Based on this argument the $\delta^{15} \mathrm{~N}$ of sinking particles around $300 \mathrm{~m}$ during the present study should have been more than $6 \%$. Saino and Hattori (1980) have found $\delta^{15} \mathrm{~N}$ as high as $\sim 12 \%$ o at $300 \mathrm{~m}$ depth in the far eastern Indian Ocean. However our data suggest the average value of $\sim 6 \%$ o for $\mathrm{BOB}$ at the same depth. This may be due to the high sinking rate of particles in the BOB allowing it lesser time for degradation. Here, the particle removal to the deep sea occurs in the form of large aggregates formed by the interaction of organic and mineral matter introduced from external sources like rivers and wind. This increases their density and consequently the settling rate in water column (Ittekkot, 1991). Minima in the $\delta^{15} \mathrm{~N}$ of PON within the surface layer as reported by Saino and Hattori (1980), has been observed during present study too, possibly due to the isotopic fractionation during nitrate uptake in light limited conditions.

\section{Conclusions}

The first systematic measurements of $\delta^{15} \mathrm{~N}$ of surface PON in BOB shows it to be a mixing between continental inputs and marine phytoplankton which consumes $\mathrm{NO}_{3}^{-}$with or without fractionation. $\delta^{15} \mathrm{~N}$ values and spatial salinity variation suggest that the surface PON of open ocean locations during both pre and postmonsoon and coastal locations during premonsoon is primarily supported by nutrients of marine origin. However, during postmonsoon coastal as well as north- ern open ocean stations are influenced by the continental run off, which leads to a dilution of $\delta^{15} \mathrm{~N}$. The depth dependent increase in $\delta^{15} \mathrm{~N}$ of suspended PON appears to be a general feature. This increase to a maximum of $2.8 \%$ is lower than that observed for the eastern Indian Ocean (Saino and Hattori, 1980) possibly due to the high settling rates of sinking particles in BOB.

Acknowledgements. We thank M. Madhupratap (deceased), coordinator, BOBPS and S. Prasanna Kumar, Chief Scientist, SK-182 and SK-191, for the opportunity to participate in the cruises. We also thank the Department of Ocean Development for providing the ship time to carry out this work, funded by ISRO-GBP, Department of Space, Government of India.

Edited by: J. Chanton

\section{References}

Altabet, M. A. and McCarthy, J. J.: Temporal and spatial variations in the natural abundance of ${ }^{15} \mathrm{~N}$ in PON from warm core ring, Deep Sea Res., Part A, 32, 755-772, 1985.

Altabet, M. A.: Variations in nitrogen isotopic composition between sinking and suspended particles: Implications for nitrogen cycling and particle transformation in the open ocean, Deep Sea Res., Part A, 35, 535-554, 1988.

Altabet, M. A. and Francois, R.: The use of nitrogen isotopic ratio for reconstruction of past changes in the surface ocean nutrient utilization, Carbon Cycling in the Glacial Ocean: Constraints on the Ocean's Role in Global Change, edited by: Zahn, R., Kaminski, M. A., Labeyrie, L., and Pederson, T. F., Springer-Verlag, New York, 281-306,1994.

Altabet, M. A.: Nitrogen and carbon isotopic tracers of the source and transformation of particles in the deep sea, Particle Flux in the Ocean, edited by: Ittekkot, V., Schafer, P., Honjo, S., and Depetris, P. J., John Wiley, New York, 155-184, 1996.

Bacon, M. P., Huh, C. A., Fleer, A. P., and Deuser, W. G.: Seasonality in the flux of natural radionuclides and plutonium in the deep Sargasso Sea, J. Mar. Res., 44, 185-201, 1985.

Cline, J. D. and Kaplan, I. R.: Isotopic fractionation of dissolved nitrate during denitrification in the eastern tropical North Pacific Ocean, Mar. Chem., 3, 271-299, 1975.

DeNiro, M. J. and Epstein, S.: Influence of diet on the distribution of nitrogen isotopes in animals, Geochimica et Cosmochimica Acta, 45, 341-351, 1981.

Dugdale, R. C. and Goering, J. J.: Uptake of new and regenerated forms of nitrogen in primary productivity, Limnol. Oceanogr., 12, 196-206, 1967.

Emerson, S. P., Quay, P., Stump, C., Wilbur, S., and Knox, M.: $\mathrm{O}_{2}, \mathrm{Ar}, \mathrm{N}_{2}$ and ${ }^{222} \mathrm{Rn}$ in surface waters of subarctic ocean: net biological $\mathrm{O}_{2}$ production, Global Biogeochemical Cycles, 5, 4969, 1991.

Farrell, J. W., Pederson, T. F., Calvert, S. E., and Nielsen, B.: Glacial-interglacial changes in nutrient utilization in equatorial Pacific Ocean, Nature, 377, 514-517, 1995.

Ittekkot, V.: Particle flux studies in the Indian Ocean, Eos, 72, $527-$ 530, 1991.

Kumar, S., Ramesh, R., Sardesai, S., and Seshshayee, S.: High new production in the Bay of Bengal: possible 
causes and implications, Geophys. Res. Lett., 31, L18304, doi:10.1029/2004GL021005, 2004.

Lourey, M. J., Trull, T. W., and Sigman, D. M.: Sensitivity of $\delta^{15} \mathrm{~N}$ of nitrate, surface suspended and deep sinking particulate nitrogen to seasonal nitrate depletion in the Southern Ocean, Global Biogeochemical Cycles, 17(3), 1081, doi:10.1029/2001GB001973, 2003.

Mariotti, A., Lancelot, C., and Billen, G.: Natural isotopic composition of nitrogen as a tracer of origin for suspended organic matter in the Scheldt estuary, Geochim. Cosmochim. Acta, 48, 549-555, 1984.

Minagawa, M. and Wada, E.: Nitrogen isotope ratios of red tide organisms in the East Chine Sea: A characterization of biological nitrogen fixation, Mar. chem., 19, 245-259, 1986.

Mino, Y., Saino, T., Suzuki, K., and Maranon, E.: Isotopic composition of suspended particulate nitrogen $\left(\delta^{15} \mathrm{~N}_{\text {sus }}\right)$ in surface waters of the Atlantic Ocean from $50^{\circ} \mathrm{N}$ to $50^{\circ} \mathrm{S}$, Global Biogeochemical Cycles, 16, 4, 1059, doi:10.1029/2001GB001635, 2002.

Miyake, Y. and Wada, E.: The abundance ratio of ${ }^{15} \mathrm{~N} /{ }^{14} \mathrm{~N}$ in marine environments, Rec. Oceanogr. Works Jpn. 9, 37-53, 1967.

Miyake, Y. and Wada, E.: The isotope effect on the nitrogen in biochemical, oxidation-reduction reactions, Rec. Oceanogr. Works Jpn. 11, 1-6, 1971.

Montoya, J. P. and McCarthy, J. J.: Isotopic fractionation during nitrate uptake by phytoplankton grown in continuous culture, J. Plankton Res., 17, 439-464, 1995.

Owens, N. J. P. and Rees, A. P.: Determination of nitrogen-15 at sub-microgram levels of nitrogen using automated continuousflow isotope ratio mass spectrometer, Analyst, 114, 1655-1657, 1989.

Prasanna Kumar, S., Muraleedharan, P. M., Prasad, T. G., Gauns, M., Ramaiah, N., De Souza, S. N., Sardesai, S., and Madhupratap, M.: Why is the Bay of Bengal less productive during summer monsoon compared to the Arabian Sea? Geophysical Research Letters, 29 (24), 2235, doi:10.1029/2002GL016013, 2002

Rau, G. H., Low, C., Pennington, J. T., Buck, K. R., and Chavez, F. P.: Suspended particulate nitrogen $\delta^{15} \mathrm{~N}$ versus nitrate utilization: Observations in Montery Bay, CA, Deep Sea Res., Part II, 45, 1603-1616, 1998

Saino, T. and Hattori, A.: ${ }^{15} \mathrm{~N}$ natural abundance in oceanic suspended particulate matter, Nature, 283, 752-754, 1980.
Saino T. and Hattori, A.: Geographical variation of the water column distribution of suspended particulate nitrogen and its ${ }^{15} \mathrm{~N}$ natural abundance in the Pacific and its marginal seas, Deep Sea Research, 34, 807-827, 1987.

Schafer, P. and Ittekkot, V.: Isotopic biogeochemistry of nitrogen in the northern Indian Ocean, Mitt. Geol. -Palaont. Inst. Univ. Hamburg, 78, 67-93, 1995.

Shetye, S. R., Shenoi, S. S. C., Gouveia, A. D., Michael, G. S., Sundar, D., and Nampoothiri, G.: Wind- driven coastal upwelling along the western boundary of the Bay of Bengal during the southwest monsoon, Cont. Shelf Res., 11, 1397-1408, 1991.

Shetye, S. R., Gouveia, A. D., Shenoi, S. S. C., Sundar, D., Michael, G. S., and Nampoothiri, G.: The western boundary current of the seasonal subtropical gyre in the Bay of Bengal, J. Geophys. Res., 98, 945-954, 1993.

Strickland, J. D. H. and Parson, T. R.: A practical handbook of seawater analysis, Fisheries Research Board, Canada, 127-130, 1972.

Subramanian, V.: Sediment load of Indian Rivers, Current Science, 64, 928-930, 1993.

Sweeney, R. E., Liu, K. K., and Kaplan, I. R.: Oceanic nitrogen isotopes and their use in determining the source of sedimentary nitrogen, in: Stable isotopes in the earth sciences, edited by Robinson, B.W., DSIR 220 New Zealand dept. Scientific and industrial, Wellington, 9-26, 1978.

Unger, D., Ittekkot, V., Schafer, P., Tiemann, J., and Reschke, S. Seasonality and interannual variability of particle fluxes to the deep Bay of Bengal: influence of riverine input and oceanographic processes, Deep Sea Res. II, 50, 897-923, 2003.

Vinaychandran, P. N. and Mathew, S.: Phytoplankton bloom in the Bay of Bengal during the northeast monsoon and its intensification by cyclones, Geophys. Res. Lett., 30 (11), 1572, doi:10.1029/2002GL016717, 2003.

Wada, E., Miyazaki, T., and Hattori, A.: ${ }^{15} \mathrm{~N}$ abundance in nitrogenous compounds in the sea, Proc. 1971 Fall Meet. Oceanogr. Soc. Japan, 227-231, 1971.

Wada, E. and Hattori, A.: Natural abundance of ${ }^{15} \mathrm{~N}$ in particulate organic matter in the North Pacific Ocean, Geochim. Cosmochim. Acta, 40, 249-251, 1976.

Wada, E. and Hattori, A.: Nitrogen isotope effects in the assimilation of inorganic nitrogenous compounds by marine diatoms, Geomicrobiol. J., 1, 85-101, 1978.

Wada, E. and Hattori, A.: Nitrogen in the sea: Forms, Abundances, and rate processes, CRC Press, Boca Raton, Fla, 208-212, 1991. 